Article

\title{
Interannual Hydroclimatic Variability of the Lake Mweru Basin, Zambia
}

\author{
Peter Waylen ${ }^{1, *}$, Christopher Annear ${ }^{2}$ (D) and Erin Bunting ${ }^{3,4}$ (D) \\ 1 Department of Geography, University of Florida, Gainesville, FL 32611, USA \\ 2 Department of Anthropology, Hobart and William Smith Colleges, Geneva, NY 14456, USA \\ 3 Department of Geography, Environment, and Spatial Sciences, Michigan State University, East Lansing, \\ MI 48824, USA \\ 4 Remote Sensing and GIS Research and Outreach Services (RS\&GIS), Michigan State University, East Lansing, \\ MI 48823, USA \\ * Correspondence: prwaylen@ufl.edu
}

Received: 25 July 2019; Accepted: 27 August 2019; Published: 29 August 2019

\begin{abstract}
Annual precipitation inputs to the Lake Mweru basin, Zambia, were computed from historic data and recent gridded data sets to determine historic (1925-2013) changes in lake level and their potential impacts on the important fisheries of the lake. The results highlight a period from the early 1940s to the mid-1960s when interannual variability of inputs doubled. Existing lake level data did not capture this period but they did indicate that levels were positively correlated with precipitation one to three years previously, reflecting the hydrologic storage of the lake, the inflowing Luapula River and the upstream Bangweulu wetland complex. Lag cross-correlations of rainfall to El Niño-Southern Oscillation (ENSO) and the Indian Ocean Dipole were weak and spatially and temporally discontinuous. The two drivers were generally positively correlated and induced opposing effects upon annual precipitation and lagged lake levels. This correlation became non-significant during the time of high observed interannual variability and basin inputs were prone to the vagaries of either driver independently or reinforcing drought/excess conditions. During times of high flows and persistent elevated lake levels, breeding habitat for fish increased markedly, as did nutrition supplied from the upstream wetlands. High hydrologic storage ensures that lake levels change slowly, despite contemporary precipitation totals. Therefore, good conditions for the growth of fish populations persisted for several years and populations boomed. Statistical models of biological populations indicated that such temporally autocorrelated conditions, combined with abundant habitat and nutrition can lead the "boom and bust" of fish populations witnessed historically in Lake Mweru.
\end{abstract}

Keywords: Lake Mweru; Zambia; annual precipitation; lake level; ENSO; Indian Ocean dipole

\section{Introduction}

The diversity and abundance of species available in the allotropic fishery of Lake Mweru are significant to local, national and international markets [1-3]. The serially autocorrelated nature of lake inputs resulting from precipitation and the large upstream Bangweulu wetland complex have profound effects on the delivery of nutrients and the availability of habits in the lake. Such temporal (hydrologic and nutrient inputs) and spatial (habitats) correlations are key factors [4] producing apparent erratic ecosystem behavior or "surprises" [5], with marked interannual variations in fish stocks.

The lake and its contributing area constitute the most southeasterly tributary of the Congo basin. Despite the Congo's impacts on deep tropical convection [6], continent-atmosphere interactions [7], ocean-atmosphere interactions and regional climates [8], little is known about the dynamics of the 
climate over the region [9]. The Mweru basin lies on the margin of influences from the Atlantic and Indian Oceans [9], juxtaposed to the East African Highlands and Rift Valley, and beneath the annual passage of the Inter-tropical Convergence Zone (ITCZ) [10]. Despite the growing interest in the hydroclimatology of the Congo [6,8,11-14], the peripheral nature of the Mweru and the paucity of historic records have resulted in its climatological characteristics being subsumed into larger geographic regions (for example, $[14,15]$ ).

The objectives of this paper were (a) to estimate historic annual precipitation inputs to the basin using station records and more recent satellite-based observations, (b) to compare inputs to limited available lake level records, (c) to identify periods of changed precipitation characteristics, and (d) to link any interannual and interdecadal variability to potential large-scale drivers of regional climate.

\section{Study Area, Climate Drivers and Data}

The basin (Figure 1), occupying $177,000 \mathrm{~km}^{2}$ in the southeastern Congo basin, consists of a series of rectilinear blocks on the western rim of the East African Highlands. The Chambeshi River gathers water from the north at over $1700 \mathrm{~m}$, disgorging southwestwards into $9000 \mathrm{~km}^{2}$ of the Bangweulu wetlands. The Luapula River exits from the wetlands over the plateau lip before flowing northwest to a long $(100 \mathrm{~km})$ delta at the southern end of Lake Mweru. The delta occupies between 1500 and $2400 \mathrm{~km}^{2}$ known as the Kifakula Depression, with scattered permanent lagoons. Lake depth varies from $3 \mathrm{~m}$ in the southeast, to $37 \mathrm{~m}$ in the northwest, near the outlet to the Luvua River [16].

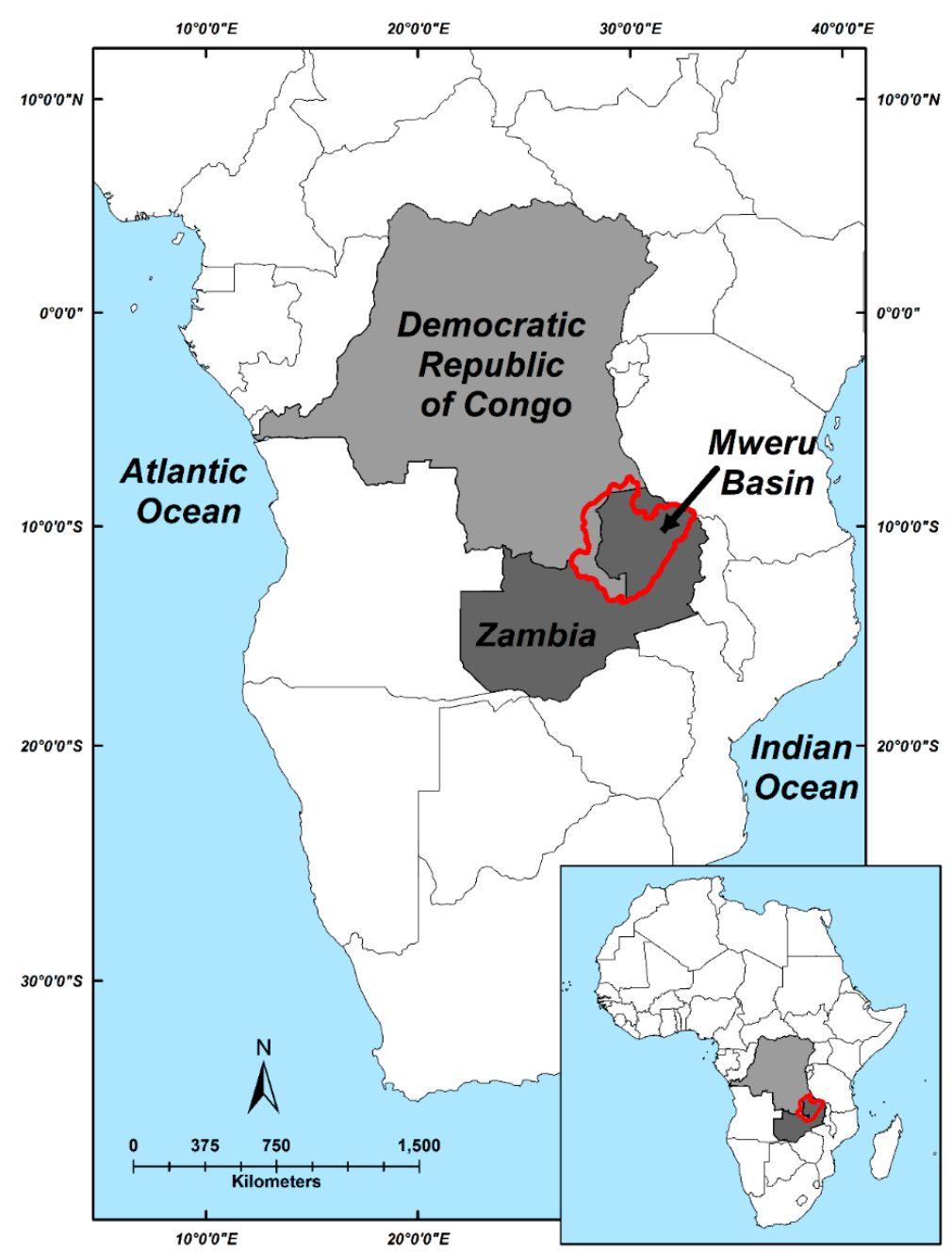

Figure 1. Location of the drainage basin feeding Lake Mweru, Zambia. 
The dominant driver of intra-annual variability of precipitation is the migration of the ITCZ [6-11]. To the south and east, the precipitation regime is highly seasonal, with as much as $70 \%$ of the mean annual total (Figure 2) falling in the wettest triad (generally Dec, Jan, F). This figure drops below 50\% in the northwest, where the more bimodal pattern of much of the Congo basin prevails. The southern African Easterly Jet (AEJ) and the Tropical Easterly Jet (TEJ) [9] also play important regional roles. The mid-tropospheric AEJ results from the contrast of hot dry (south) and humid equatorial (north) conditions and steers African Easterly Waves and mesoscale convective storms (MCS) across the study area [17-19]. The upper level exit region of the TEJ over eastern equatorial Africa during austral summer enhances surface convection [18]. The wettest conditions are associated with synchronous southern displacement of the ITCZ and AEJ, and a northern displacement of the TEJ, conjoining over the basin [9].

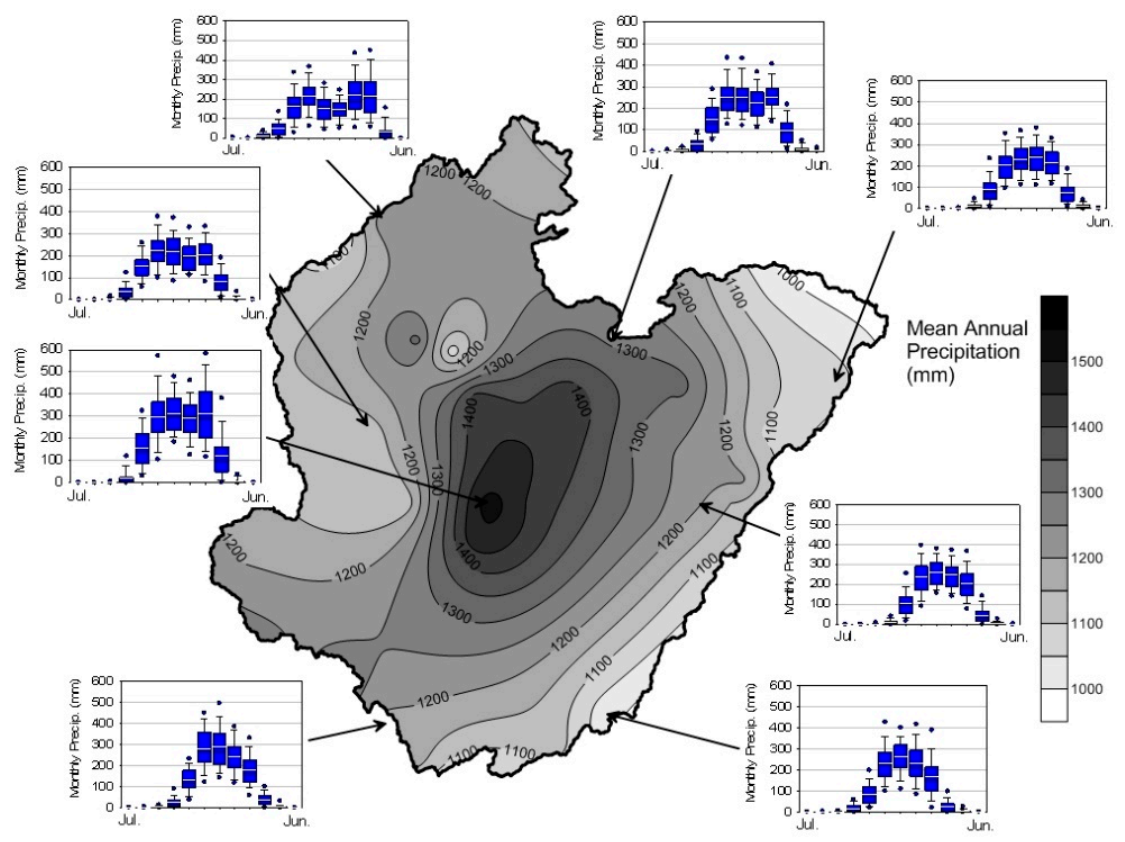

Figure 2. Estimated mean annual precipitation in the Mweru basin, 1925-1986, displaying box and whisker diagrams of monthly historic precipitation at selected sites. The dots represent the fifth and 95th percentiles, the whiskers the 10th and 90th, the boxes the 25th and 75th and the white horizontal bars, the means.

The basin lies between two established poles, of opposing responses to El Niño-Southern Oscillation (ENSO) [20]—southeast Africa and equatorial East Africa. The nature and strength of the linkage between ENSO and East African precipitation undergoes interdecadal change governed by atmosphere-ocean exchanges over the Indian Ocean [21-27]. The Indian Ocean Dipole (IOD) and the Southern Indian Ocean Dipole (SIOD) have been proposed to represent these interactions [24,28-34].

Atlantic moisture can penetrate as MCSs within the southwest monsoonal flow as far as the eastern Congo basin [35-37], enhanced by a strong mid-tropospheric EAJ [38]. Moisture availability may be controlled by pseudo-periodic changes in sea surface temperatures (SSTs) off southwest Africa [39,40]. Years of excess flow in southern Angola correspond to increased precipitation along the general orientation of the ITCZ passing through the Mweru basin [41]. Additional complexity may arise from feedback between outflows from Congo River, SSTs and salinity of the Gulf of Guinea [8], which influence the position of the ITCZ and associated jet streams [19], inter-ocean contrasts in temperatures across equatorial Africa [12], and moisture entering the Congo basin via the West African Jet [9].

The monthly precipitation totals from 67 stations lying within a rectangle $\left(7^{\circ}-14^{\circ} \mathrm{S}, 26^{\circ}-33.5^{\circ} \mathrm{E}\right)$ describing the basin are available from the Global Historic Climate Network of the National Climate Data Center [42]. As the precipitation regime displays a strong austral summer maximum (Figure 2), 
data were aggregated over a water year running from July to June. Only water years returning twelve complete monthly records were considered. The period 1925 to 1986, during which at least 30 stations reported complete records, was initially examined. Kriged surfaces were fit to the data points available each year, volume under the surfaces within the basin extracted, and the average depths of precipitation computed (Figure 3).

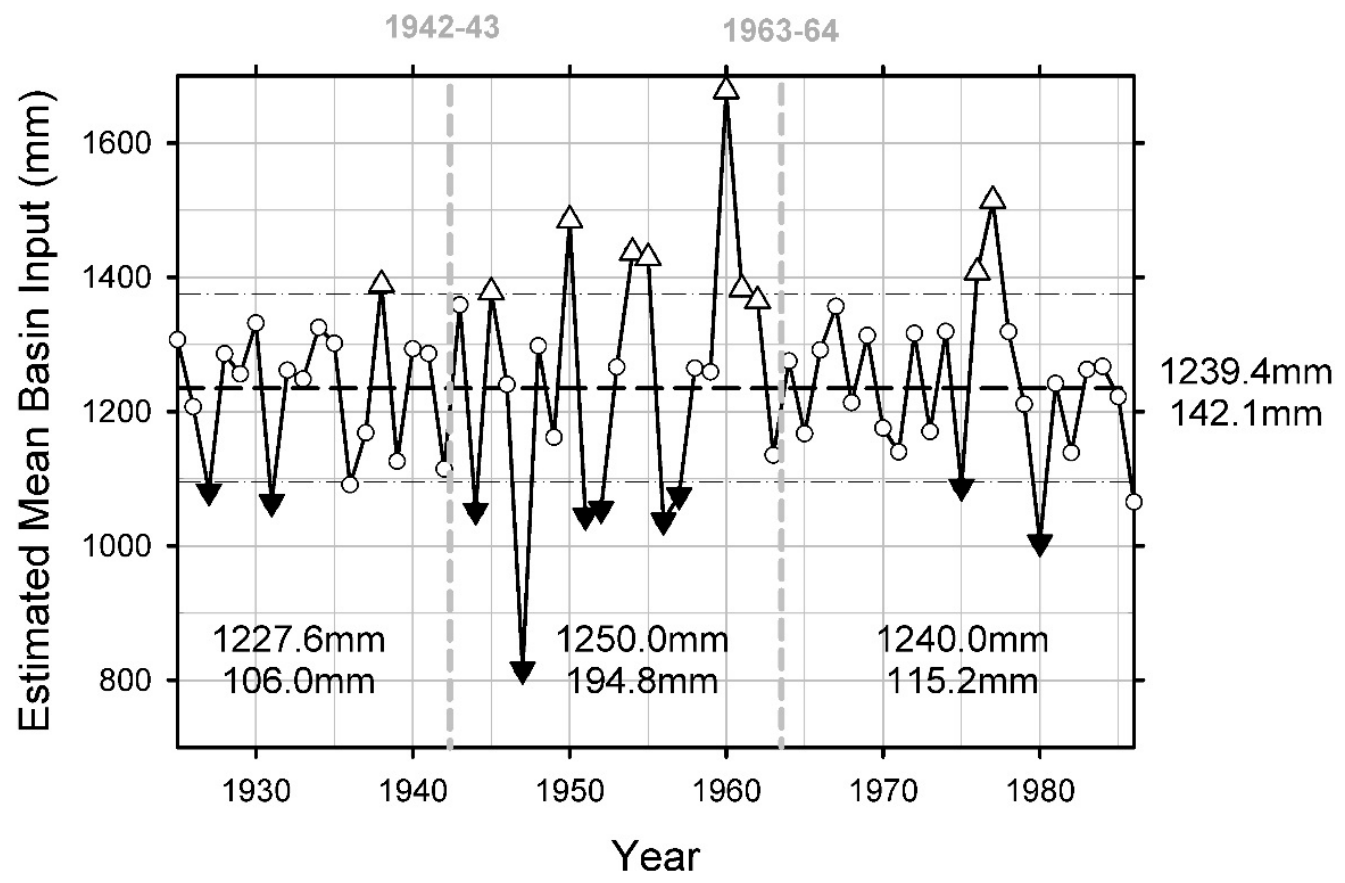

Figure 3. Estimated annual precipitation input to the Mweru basin, 1925-1986. The open triangles mark the ten largest inputs and the inverted solid triangles the ten smallest. The black horizontal dashed line represents the long-term mean and the lighter dot-dashed lines the mean $+/-$ one standard deviation. The heavy grey vertical lines delimit three arbitrarily defined periods and their respective means (upper) and standard deviations (lower).

Additional rainfall estimates (1986-2014) were extracted from the gridded African Rainfall Climatology version 2 (ARC2) [43]. All data processing was completed in R using the 'raster' package [43]. After reading, daily raster layers were stacked in individual monthly rasters and then were summed to create annual water year totals for all of the grid cells in the study area [44]. The extended Multivariate ENSO Index (MEI) was used to indicate ENSO phase because of its historic extent and the number of variables involved [45]. The MEI and monthly Dipole Mode Index (DMI), used to indicate the state of the Indian Ocean [46], were computed based on the water year, and lake levels, 1953-1986, were extracted from [16]. The decades over which lake level data are available cover decades of important social change in Zambia. Changes in land use/land cover in parts of the basin may have altered rainfall/runoff relationships. However, no such association was noted [16] and preliminary analysis of the lake level data revealed no marked changes other than those accounted for by annual precipitation input.

Analytical methods were limited to variants of correlation, including serial autocorrelation within the time series of variables, and lag cross correlations between time series.

\section{Results}

\subsection{Temporal Variability}

Figure 3 evinces a consistent mean annual input of about $1240 \mathrm{~mm}$, and considerable inter-decadal variability. A two-sample F-test revealed that variances during the first and last periods were 
significantly different from that of the intervening one. All tests were performed at the 0.05 level unless otherwise stated. Appropriate (equal/unequal variances) t-tests of means showed no significant difference between periods. According to a non-parametric test using the hypergeometric probability distribution, the probability of observing at least seven of the wettest years in the period 1943-1965 at random was 0.013 , and that of finding at least six of the driest is 0.064 , supporting the notion of increased interannual variability during this period. Significant autocorrelation of inputs (Figure 4) occurred at lags of three (negative) and five (positive) years, corresponding to peaks in the spectra of East African rainfall $[47,48]$. Such variability translates to the delivery of nutrients into Lake Mweru and to the periodic expansion and contraction of wetlands (favorable fish habitats) at the shallow southern end of the lake. This temporally and spatially autocorrelated condition is a prerequisite for rapid and unexpected changes in biological populations [4]. The lag cross-correlogram of lake levels and inputs (Figure 5) shows the two to be out of phase, but positively correlated at lags of one to three years. The large upstream storage of the upper Chambeshi basin, the extensive Bangweulu wetland complex, the Luapula wetlands and the lake itself, comprised a cascade of hydrologic stores attenuating downstream response. The significant cross-correlation at a lag of eight years was equivalent to the positive serial correlation at a lag of five years in the precipitation input series (five-year periodic behavior, plus the two- to three-year lag caused by land-based hydrologic storage). Although not significant, the negative lag cross-correlation at a lag of five years corresponds to the negative serial correlation in the input series at a lag of two years.

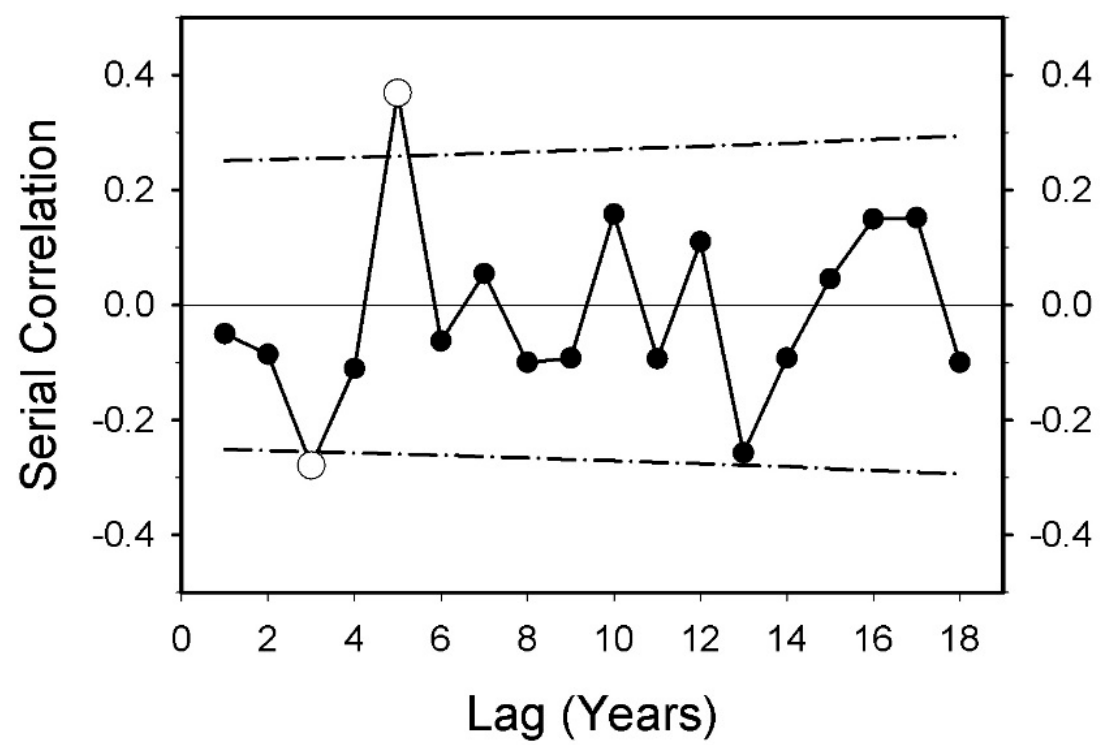

Figure 4. Autocorrelogram of annual precipitation inputs to Mweru basin. Upper and lower 95\% confidence bound shown as dashed lines.

The search for teleconnections and their changing nature relied heavily upon the use of correlation. Multiplicity in correlations and autocorrelation structures may lead to spurious results unless corrected appropriately. The recommended corrections were made throughout using a value of $\mathrm{k}=3$ (precipitation, MEI and DMI) and first order autocorrelations of $-0.050,0.148$ and 0.186 respectively [49]. 


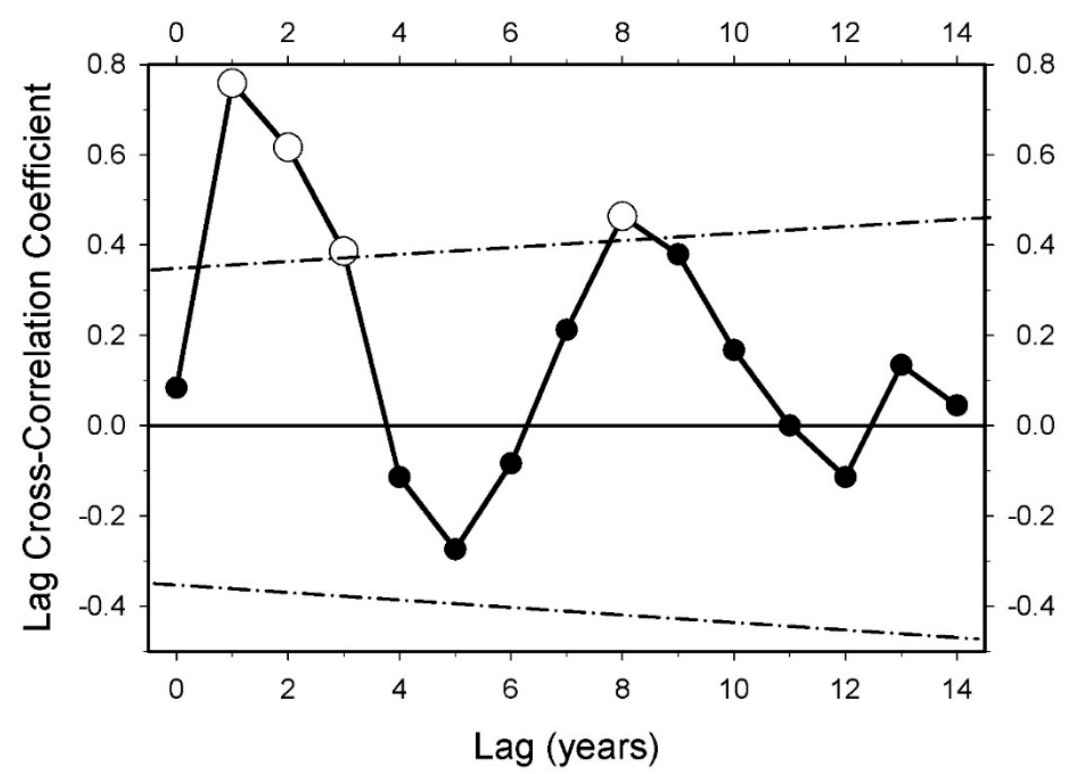

Figure 5. Lag cross-correlation between annual precipitation basin input and lake level. Precipitation leading lake level by the number of years is shown on the horizontal axis. The dotted lines represent the $95 \%$ confidence bounds.

\subsection{Potential Drivers}

Figures 4 and 5 imply periodic forcing of the input series and lake levels. The significant lags (three to eight years) suggest an impact of ENSO. However only seven of the 67 stations returned significant correlations between annual precipitation and the MEI. This weak, spatially patchy, negative association matches that identified for early season (Oct, Nov, Dec) precipitation [34] and may arise from the basin's position between two established poles of association with ENSO [20,24,34]. Significant associations between OND precipitation and the DMI occurred mainly in the northeastern part of the basin [34].

\subsection{Extension of Precipitation Record}

Satellite-derived estimates of precipitation may overcome the paucity of station data after 1986. However, the mean annual precipitation estimated from gridded data (1987-2013) was only $1045.6 \mathrm{~mm}$ compared to that from historic data of $1239.4 \mathrm{~mm}$, while standard deviations are comparable $(133.6 \mathrm{~mm}$ and $142.1 \mathrm{~mm}$ ) (Figure 6 upper). Similar differences comparing gridded precipitation data sets for East Africa have been noted [27]. Since the research focus was interannual and inter-decadal variability, this bias is potentially correctable by standardizing each portion of the series to its own mean and variance and deriving a combined standardized index of annual precipitation input. Many studies employ a Standardized Precipitation Index (SPI) [50-52], which maps the cumulative probability of an appropriate distribution as an equivalent z-score on a standard normal distribution. In this study, annual totals approximate a normal distribution, thus a simple z-score was all that was necessary.

There is no discernible break in the combined standardized series as the data source changes (Figure 6 lower). Serial correlations (Figure 7) in the observed, gridded and combined standardized series yielded similarities, most notably at lag 3 . Serial correlation of the gridded data at this lag was similar in magnitude to that of the historic data, although the reduced sample size places it within the confidence limits. A marked difference in the overall pattern of correlations occurred at lag 5, which was significantly positive in the data derived from historic station data (and therefore, also in the combined record), whereas the shorter gridded data set yielded a negative correlation. 


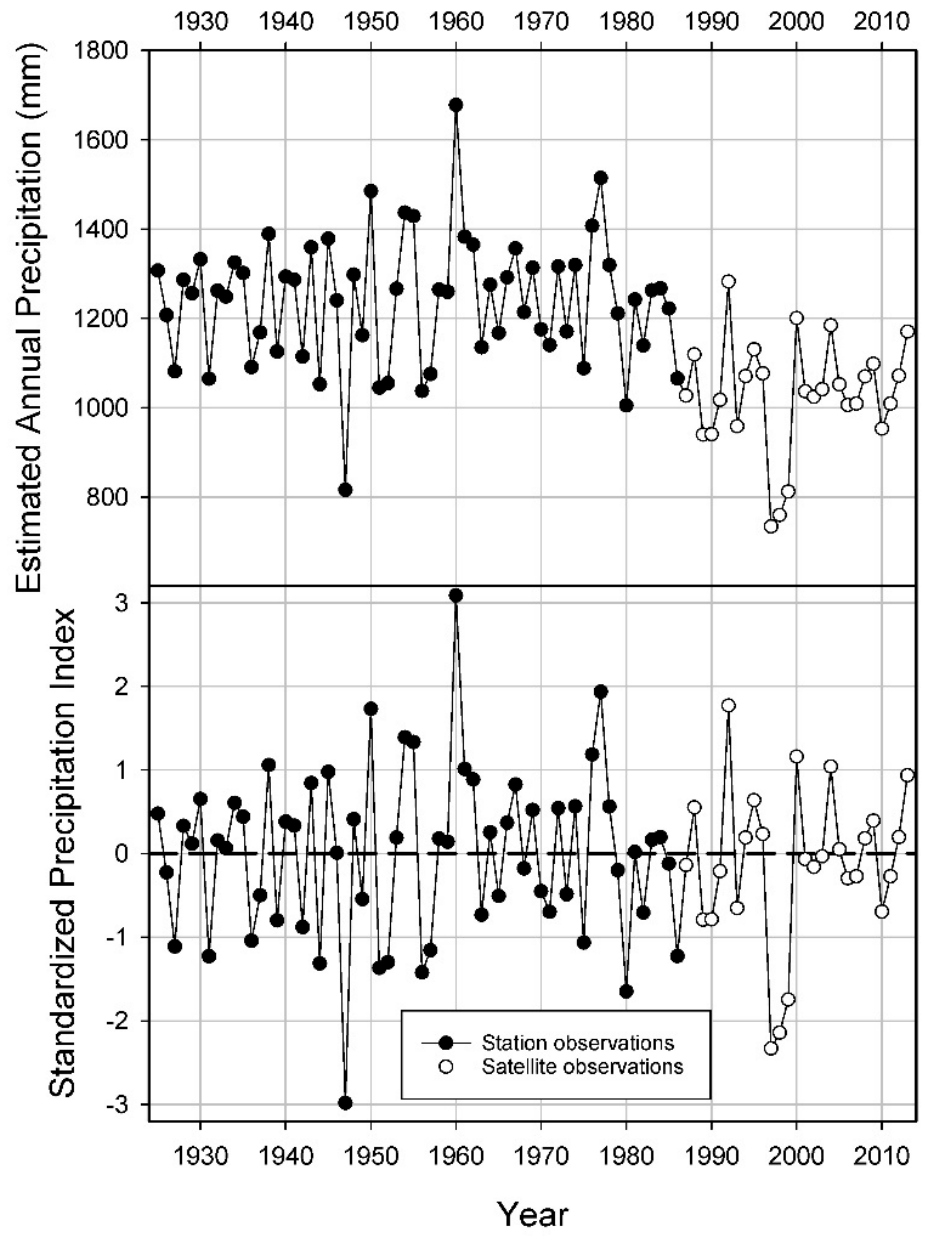

Figure 6. (Upper) Combined time series of inputs $(\mathrm{mm})$ based on historic station records (closed symbols) and gridded data (open symbols). (Lower) Combined time series once the two data sets were standardized by their respective means and standard deviations.

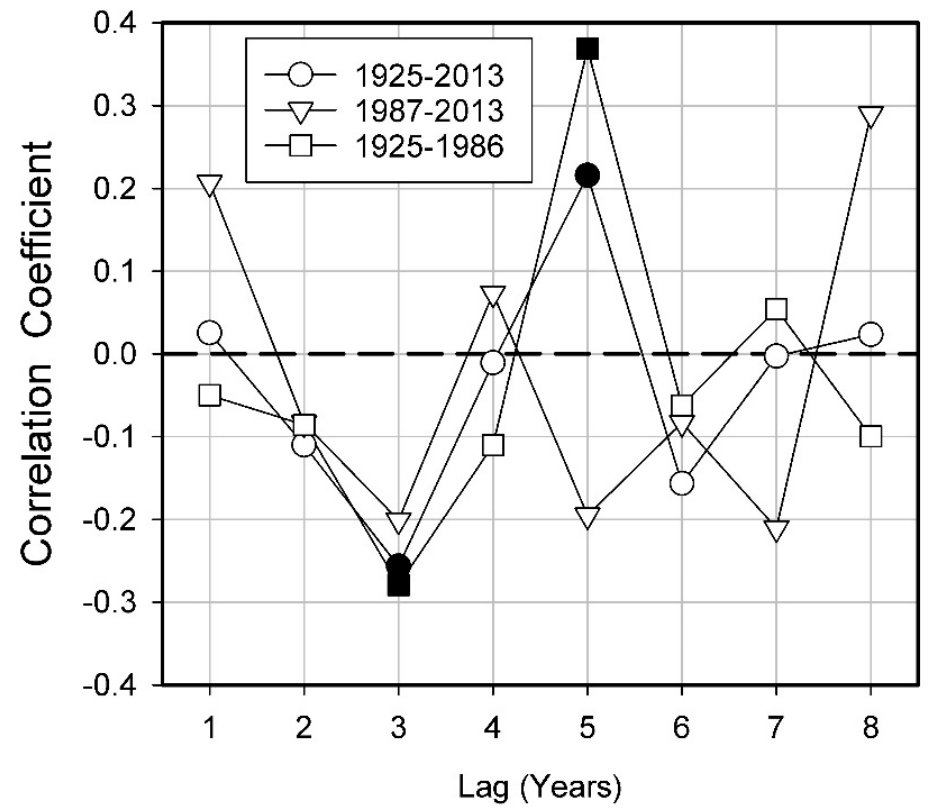

Figure 7. Autocorrelation of estimated annual basin precipitation inputs based on historic station data, gridded data and the combined standardized precipitation index. The significant correlations are shown by filled symbol. 


\subsection{Potential Changing Impacts of Drivers}

The different autocorrelation structure of inputs in the most recent period (gridded data) (Figure 7) might reflect a changing interaction between the IOD and ENSO in East Africa [24,28-34]. Lag-cross correlations between the standardized precipitation index and the DMI and MEI were viewed through a 21-year sliding window (Figure 8). Fifteen lags were employed from +7 (precipitation precedes ocean atmosphere index) to -7 (precipitation follows the index) to amply ensure that associations at all feasible lags were captured.

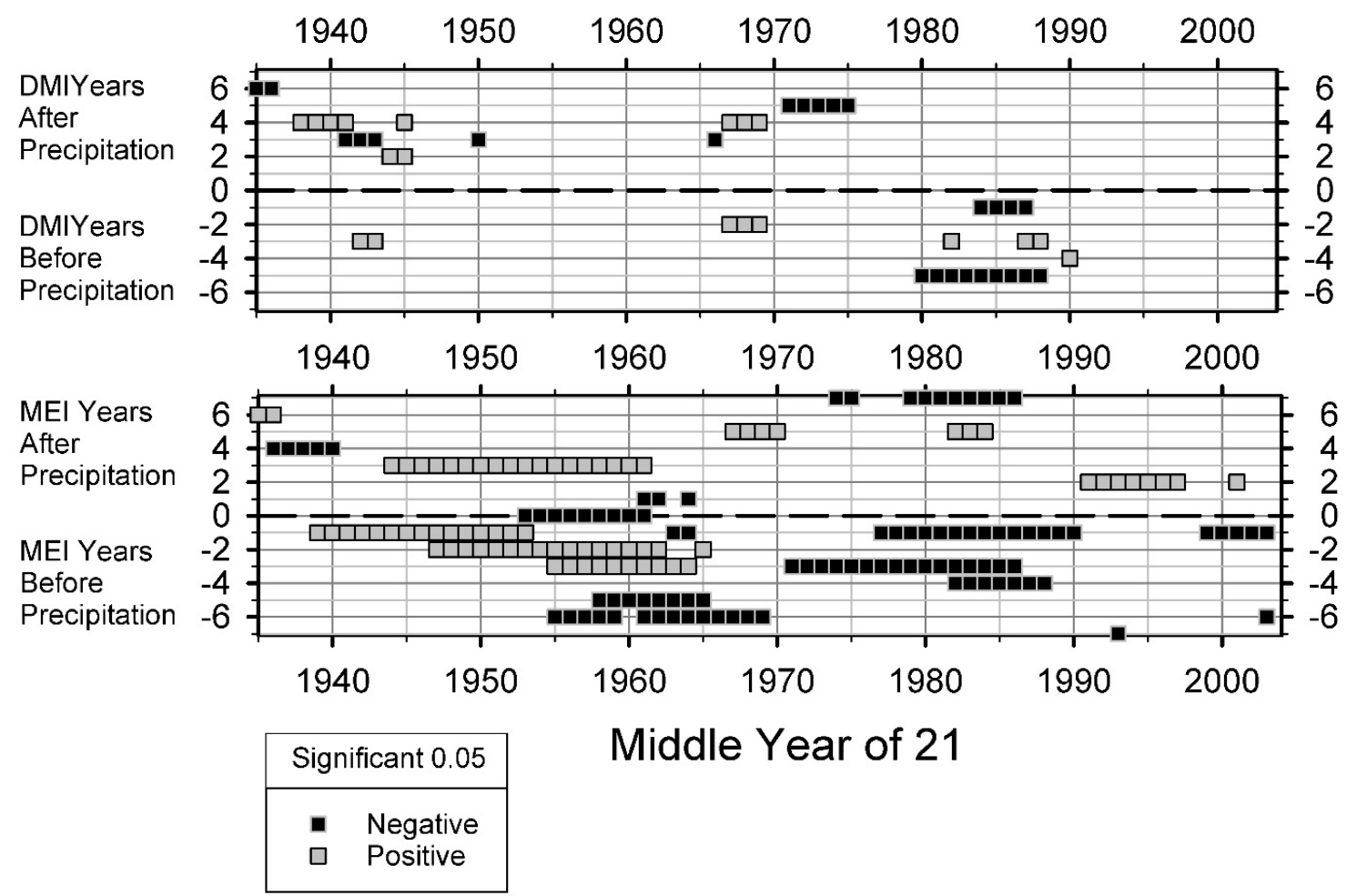

Figure 8. Significant lag-cross correlations between standardized precipitation (1925-2013) and the DMI (upper) and MEI (lower) viewed through a 21-year window over lags +7 to -7 years.

A small number of significant associations between the DMI and precipitation emerged, but the majority of significant associations occurred in precipitation following MEI at lags of one to three years. However, the sign of the relationship with MEI changed through the record. Positive associations prevailed during the period of high interannual variability. Negative associations emerged in the 1970s and 1980s, and possibly most recently.

Alone, these observations do not explain the unusually high interannual variability; however, changing interactions between MEI and DMI are a possibility. Figure 9 indicates that over the period of available indices (1871-2014), the correlation structure, derived using a similar 21-year window, was significantly negative at lag zero with a discontinuity between the late 1930s and mid-1960s, and a second lacuna commencing in the late 1990s, both periods of high interannual variability.

When lag 1 correlations between precipitation (Figure 8) and the indices (Figure 9) are considered, a picture emerges (Figure 10). Although periods before 1940 and after the mid-1960s indicate the same correlation between the indices, the nature of their correlation with basin precipitation changed from more positive to negative (most pronounced for MEI). In the former period, cold phases of ENSO (negative MEI) might have induced droughts, while the accompanying positive DMI would have produced a counteracting tendency towards excess rains, and vice-versa. In the latter period, excess rains associated with negative MEI accompanied positive DMI and reduced rains. Therefore, despite the reversal of the signs of association between the indices and basin precipitation from the former 
(pre-1940) and latter periods (post-1965), the tendencies towards excess or deficit rainfall induced by each index seemed to counteract the effect of the other, i.e., the amplitude of the interannual variability was dampened. From the mid-1940s to the mid-1960s, the correlation between the two indices approached zero and the potential negating effect of the two disappeared, inducing far greater interannual variability, particularly in association with the MEI and ENSO.

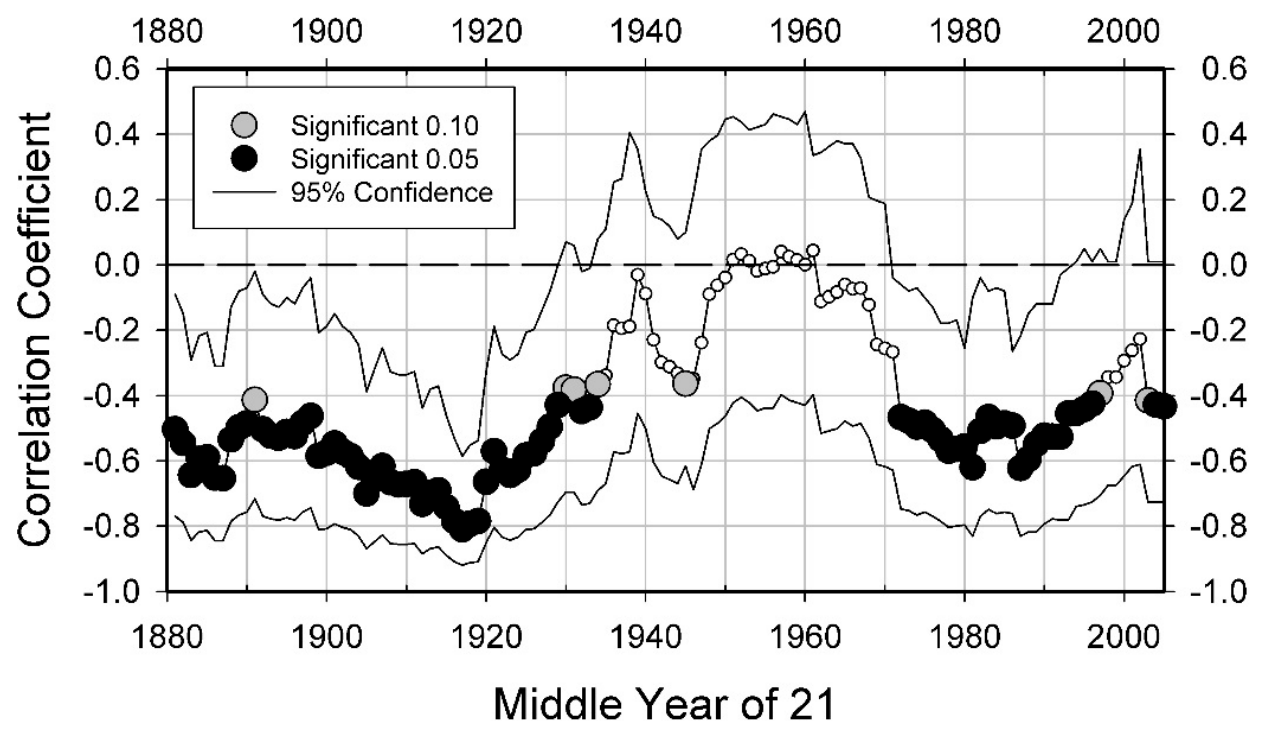

Figure 9. Lag zero cross correlations between annual DMI and MEI 1871-2015 viewed through a 21 -year window. Confidence bounds (95\%) around estimated coefficients shown for reference.
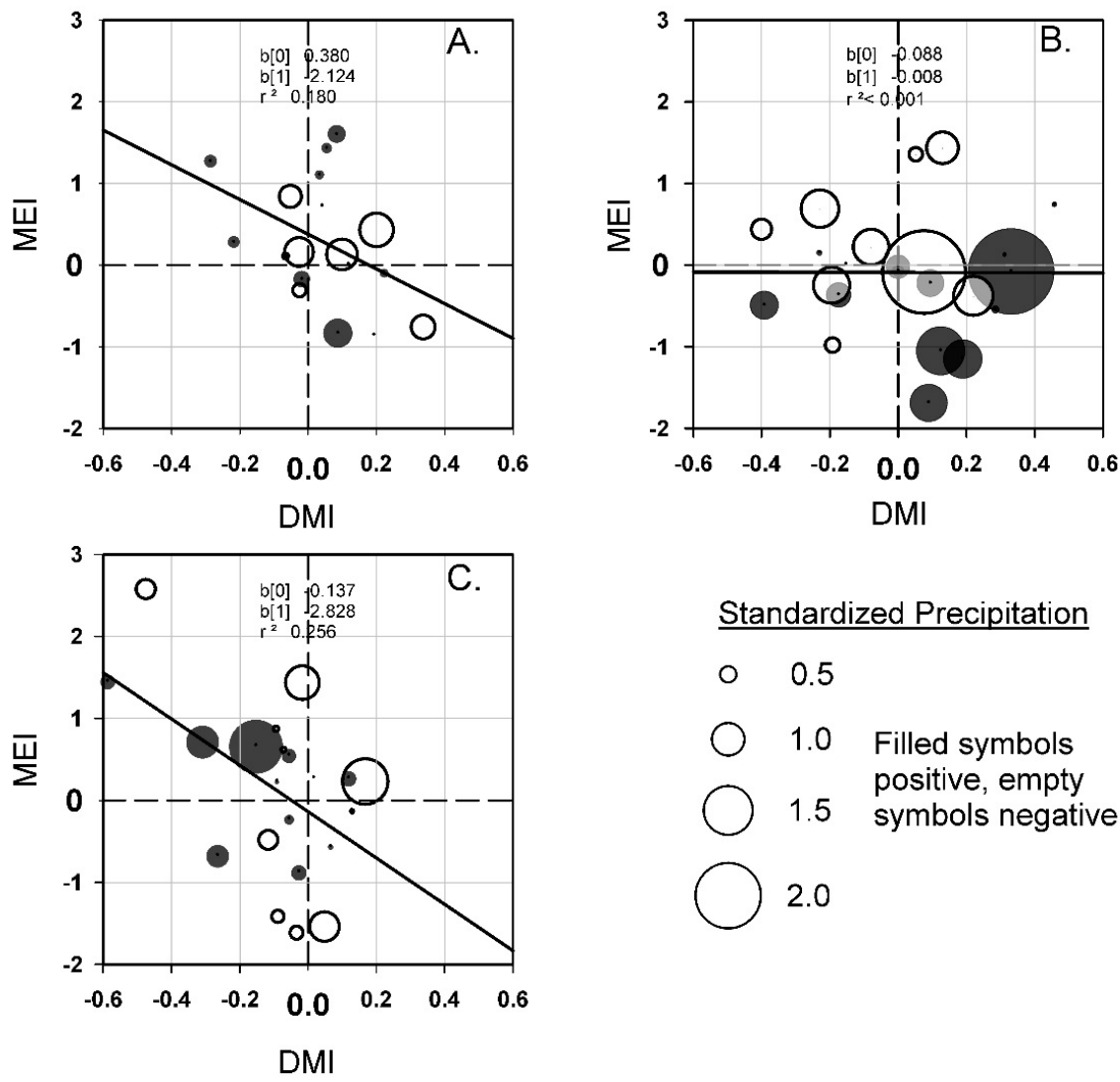

Figure 10. Bubble plots of DMI, MEI and standardized precipitation during (A) 1925-1942,(B) 1943-1965,

(C) 1966-2013, reporting best fit straight lines, intercepts, slopes and correlation coefficients. 


\section{Discussion}

Despite the minimum annual requirement of 30 operating stations, the varying numbers and locations of stations used to estimate basin input were a weakness, as was the change in the estimated mean level of input corresponding to the extension of the record after 1986. However, the stated focus on the temporally changing nature of interannual variability of precipitation rather than mean levels and the apparent agreement of the overall findings with work in a broader continental context serve to alleviate those concerns.

The small sample size of annual precipitation totals prior to the noted shift in interannual variability and the use of the 21-year moving window for correlations make the statements concerning behavior during this period tenuous. However, the period of rainfall observations is placed in historic context as the association between the two indices can be extended back to 1871 (Figure 9), indicating that the mid-1920s to mid-1940s represents the end of a protracted period during which the MEI and DMI were strongly negatively correlated.

The relaxation of the correlation between the two phenomena during the second period mirrors that reported elsewhere [23] and its re-initiation by the 1970s corresponds to the "new type" of IOD [53]. A similar theory of "destructive interference" [32] was invoked to explain changes in patterns of rainfall and photosynthesis across Africa in 1982-2003. Three of the regions studied, "Tanzanian", "Congo (DRC)" and "SE African", circumscribe the limits of the Mweru basin without intersecting. The "Tanzanian" and "SE Africa" regions have great sensitivity to ENSO, while the "Tanzanian" and "DRC" show impacts of IOD. Although the geographic limits of a study [48] far exceed those of the Mweru basin, the standardized rainfall departures in Eastern Africa, specifically in the region south of Lake Victoria, demonstrate some of the most extreme values during this period. In southeastern Australia [53], these changes in correlation correspond to the end of a drought from 1935-1945, and the beginning of a shorter drought 1965-1971.

Despite the congruence of the results with those of research in surrounding areas, a satellite-based study of levels of Lake Mweru (1993-99) [54] appears to refute the conclusions; showing levels varying seasonally around a fairly consistent mean, increasing dramatically (1-2 m) in 1998 and decreasing a little in 1999. This pattern is ascribed to "important rainfall" over parts of central east Africa 1997-1998, and refers to supporting research by $[55,56]$. The gridded data estimates of basin precipitation-raw or standardized (Figure 6)—show contemporary inputs to the Mweru basin approximately two standard deviations below normal.

This apparent contradiction can be primarily explained by the lead-lag relationship observed between annual precipitation and lake levels (Figure 5). Given the significant positive associations between annual input and lake levels one, two and three years later, the rise in Lake Mweru observed in 1998 [54] is more likely to be reflective of precipitation inputs over the period 1995-1997, all of which are above average (Figure 5). The cumulative effect of such a series would result in the 1998 increase in level, even though contemporary input was considerably lower than average. There is also the issue of the comparative scale of fluctuations witnessed 1993-1999. In this short time span, the observed increase of 1-2 m seems extremely large; however, placed in the broader context of 1955-1992 levels [16], such changes do not require the unusually large postulated inputs. One source of supporting evidence [55] examined (a) only basins north and east of Lakes Tanganyika and Malawi and (b) precipitation in ONDJ, yet Figure 2 shows that equally large quantities fall in the Mweru during February and March. The spatial extent of the 1997-1998 excess rainfalls is delimited by a study of monthly (1997-2000) NDVI in East Africa (15 ${ }^{\circ} \mathrm{N}$ to $\left.35^{\circ} \mathrm{S}\right)$, including the Mweru basin [57]. The impacts on inland regions is limited to north of the equator-in fact, vegetation in the Mweru returns slight $(<10 \%)$ decreases in NDVI, suggesting drying. The extensive wetlands and moisture storage within the basin may be responsible for buffering the impact of such a drought experienced in southeastern Africa during the major warm phase ENSO of 1997. The passing reference made to the 1997-1998 event [56] suggests that responses of rainfall in areas identified by [55,57] would likely be the opposite of that over the Mweru basin. 
Biological populations in a spatially heterogeneous environment can continue to exist even when predation exceeds the rate of reproduction if there is recurrent migration from areas where reproduction exceeds predation [4]. Here, the fish population in the coupled a lake/wetland system of the bathymetric complexity of Lake Mweru and influent Luapula River constitutes the biological population. It continues to exist even when predation by local fishers exceeds rates of reproduction in populations that are not heavily density-dependent (where population growth rates are not limited by such factors as the availability of habitat and food), as there can be periods during which environments which are generally sinks (areas of predation), become transient sources (areas of reproduction). The autocorrelation structure of temporal variations plays an important role in the trajectory of populations in such source and sink systems. In closed populations dominated by density-dependent processes (shortages of habitat/food), the persistence of poor conditions leads to predation and loss of population that cannot be restored during good conditions and possible extinction. Conversely, if the density-dependent processes become less important, autocorrelation produces the opposite impact; population growth in the source areas is not as strictly capped and colonization of the sink zones may exceed predation. Under these circumstances, positive temporal autocorrelation in growth rates can enhance the overall population size in an inflationary effect, while colonization sustains the sink areas during periods of less favorable conditions and the entire population expands rapidly during a series of good years. Under conditions of temporal autocorrelation and inflationary effect, even if all environments are considered long-run sinks (excessive fish capture), populations can be sustained and be inflated rapidly to very high levels [4].

The hydroclimatology of Lake Mweru and its adjoining wetlands of the Luapula River exhibit strong autocorrelation and periodicities. Increases in lake level produce large increases in potential breeding grounds at the gently sloping southern end of the lake and through the flooded wetlands of the Luapula River and Kifakula Depression, which may expand as wide as $14 \mathrm{~km}$ [16]. Statistical evidence suggests that such conditions persist up to three years after the rainfall; therefore, suitable habitat availability will not provide a strong density-dependence. The observed lag-cross correlation structure arises partially from the immense upstream storage in the nutrient-rich Bangweulu wetlands. Nutrients are delivered contemporary to the expansion of habitat (sources), further reducing density-dependence and establishing ideal conditions for fisheries to be sustained and even for rapid increases in some populations [2]. The same hydroclimatologic controls act to produce persistent poor years, however, they do not result in the extinction but in wild fluctuations of populations. Such fluctuations and persistence have been ascribed to poor management of the local fishers rather than the basin's local topography, climatology and hydrology, compounded by periodicities induced by global scale phenomena. These conspire to produce a biological system displaying such characteristics even without human predation.

\section{Conclusions}

The Lake Mweru basin lies between two well-established regions of opposing "poles" of hydroclimatic response to phases of ENSO and the IOD. Any climatic variability has direct consequences upon lake levels, the availability of breeding habitat, and nutrient supply, which in turn affect the variety and numbers of fish available. The most apparent non-stationarity in annual precipitation input is in the interannual variability, between the early 1940s to the mid-1960s, corresponding to decades in which the association between two external drivers, the MEI and DMI, disappeared. For the bulk of the period 1871-2015, significant negative correlations prevailed and induced opposing effects upon rainfall—“destructive interference" [32]—dampening interannual variability. When that regulating correlation was absent, interannual variability doubled.

Large lakes inevitably produce autocorrelative behaviors in their outflows and levels. The series of cascaded stores present in the basin attenuates interannual variability in flows, delaying the response of Lake Mweru and simultaneously delivering nutrients from the organic-rich wetland. Lake levels 
display significant correlations with rainfall inputs at lags of between one and three years, suggesting a pseudo-periodicity of seven years.

The hydroclimatology of the basin and the hydrography of the lake and influent Luapula River satisfy the conditions required for wildly fluctuating fish populations. The strong natural periodicity, related to ENSO and the IOD and attenuated by basin storage, introduce the necessary serial (and spatial) autocorrelation in breeding habit and nutrient supply. Under these conditions, biological populations can expand rapidly in sequences of "good" years and retreat during "poor" years, avoiding extinction even though in any one or more of those "poor" years, predation exceeds reproduction [4]. Thus, distant changes in ocean-atmosphere interactions and conditions upstream of the lake itself impinge upon the lives of the local fishers, and external perceptions of (mis)management of this resource.

Author Contributions: Initial interest in and fieldwork with the communities around Lake Mweru, C.A.; Conceptualization P.W. and C.A.; Methodology P.W. and E.B.; Software; E.B.; Analysis and Validation, P.W.; Original draft preparation, P.W.; Review and editing C.A. and E.B.

Acknowledgments: The authors wish to thank Andre McFadden II for his analysis of some station data, Brian Child for recognizing that P.W. and C.A. should meet to consider this problem, and Greg Glass for his discussion of the dynamics of biological populations.

Conflicts of Interest: The authors declare no conflict of interest.

\section{References}

1. Annear, C.M.; Waylen, P.R. Socializing the rain: Human adaptation to ecological variability in a fishery, Mweru-Luapula, Zambia. J. Pol. Ecol. 2019, 26, 224-242. [CrossRef]

2. Zwieten, P.A.M.; van Goudswaard, P.C.; Kapasa, C.K. Mweru-Luapula is an open exit fishery where a highly dynamic population of fishermen makes use of a resilient resource base. In Management, Co-Management or No Management: Major Dilemmas in Southern African Freshwater Fisheries: Case Studies; Jul-Larsen, E., Kolding, J., Overa, R., Raakjaer Nielsen, J., van Zwieten, P.A.M., Eds.; FAO: Rome, Italy, 2003; Volume 2.

3. Van Zwieten, P.A.M.; Kapasa, C.K. Lake Mweru-Luapula. Analysis of the Gillnet Surveys of 1982 to 1985 and 1994 to 1996; Department of Fisheries: Nchelenge, Zambia, 1996.

4. Roy, M.; Holt, R.; Barfield, M. Temporal autocorrelation can enhance the persistence and abundance of metapopulations comprised of coupled sinks. Am. Nat. 2005, 166, 246-261. [CrossRef]

5. Holling, C.S. The resilience of terrestrial ecosystems: Local surprise and global change. In Sustainable Development of the Biosphere; Clark, W.C., Munn, R.E., Eds.; Cambridge University Press: Cambridge, UK, 1986.

6. Washington, R.; James, R.; Pearce, H.; Pokam, W.M.; Moufouma-Okia, W. Congo Basin rainfall climatology: Can we believe the climate models? Philos. Trans. R. Soc. B Bio Sci. 2013, 368, 20120296. [CrossRef]

7. Makarieva, A.M.; Gorshkov, V.G.; Li, B.L. Precipitation on land versus distance from the ocean: Evidence for a forest pump of atmospheric moisture. Ecol. Complex. 2009, 6, 302-307. [CrossRef]

8. Materia, S.; Gualdi, S.; Navarra, A.; Terray, L. The effect of Congo River freshwater discharge on Eastern Equatorial Atlantic climate variability. Clim. Dyn. 2012, 39, 2109-2125. [CrossRef]

9. Farnsworth, A.; White, E.; Williams, C.J.; Black, E.; Kniveton, D.R. Understanding the largescale driving mechanisms of rainfall variability over Central Africa. In African Climate and Climate Change; Springer: Berlin/Heidelberg, Germany, 2011; pp. 101-122.

10. Mutai, C.C.; Ward, M.N. East African rainfall and the tropical circulation/convection on intraseasonal and interannual timescales. J. Clim. 2000, 17, 3915-3939. [CrossRef]

11. Dezfuli, A.K.; Nicholson, S.E. The relationship of rainfall variability in western equatorial Africa to the tropical oceans and atmospheric circulation. Part II: The boreal autumn. J. Clim. 2013, 26, 66-84. [CrossRef]

12. Dezfuli, A.K.; Zaitchik, B.F.; Gnanadsikan, A. Regional atmospheric circulation and rainfall variability in south equatorial Africa. J. Clim. 2015, 28, 809-818. [CrossRef]

13. Jury, M.R. A return to wet conditions over Africa: 1995-2010. Theor. Appl. Clim. 2013, 111, 471-481. [CrossRef]

14. Nicholson, S.E.; Dezfuli, A.K. The relationship of rainfall variability in western equatorial Africa to the tropical oceans and atmospheric circulation. Part I: The boreal spring. J. Clim. 2013, 26, 45-65. [CrossRef] 
15. Balas, N.; Nicholson, S.E.; Klotter, D. The relationship of rainfall variability in West Central Africa to sea-surface temperature fluctuations. Int. J. Clim. 2007, 27, 1335-1349. [CrossRef]

16. Bos, A.R.; Kapasa, C.K.; van Zwieten, P.A. Update on the bathymetry of Lake Mweru (Zambia), with notes on water level fluctuations. Afr. J. Aquat. Sci. 2006, 31, 145-150. [CrossRef]

17. Leroux, S.; Hall, N.H. On the relationship between African easterly waves and the African easterly jet. J. Atmos. Sci. 2009, 66, 2303-2316. [CrossRef]

18. Nicholson, S.E.; Grist, J.P. The seasonal evolution of the atmospheric circulation over West Africa and equatorial Africa. J. Clim. 2003, 16, 1013-1030. [CrossRef]

19. Nicholson, S.E. A revised picture of the structure of the "monsoon" and land ITCZ over West Africa. Clim. Dyn. 2009, 32, 1155-1171. [CrossRef]

20. Ropelewski, C.F.; Halpert, M.S. Global and regional scale precipitation patterns associated with the El Niño/Southern Oscillation. Mon. Weather Rev. 1987, 115, 1606-1626. [CrossRef]

21. Reason, C.J.C.; Allan, R.J.; Lindesay, J.A.; Ansell, T.J. ENSO and climatic signals across the Indian Ocean basin in the global context: Part I, Interannual composite patterns. Int. J. Climatol. 2000, 20, 1285-1327. [CrossRef]

22. Shi, G.; Ribbe, J.; Cai, W.; Cowan, T. Multidecadal variability in the transmission of ENSO signals to the Indian Ocean. Geophys. Res. Lett. 2007, 34, L09706. [CrossRef]

23. Yuan, Y.; Li, C. Decadal variability of the IOD-ENSO relationship. Chin. Sci. Bull. 2008, 53, 1745-1752. [CrossRef]

24. Manatsa, D.; Matarira, C.H.; Mukwada, G. Relative impacts of ENSO and Indian Ocean dipole/zonal mode on east SADC rainfall. Int. J. Clim. 2011, 31, 558-577. [CrossRef]

25. Yang, W.; Seager, R.; Cane, M.A.; Lyon, B. The East African long rains in observations and models. J. Clim. 2014, 27, 7185-7202. [CrossRef]

26. Wang, J.; Yuan, D. Roles of western and eastern boundary reflections in the interannual sea level variations during negative Indian Ocean dipole events. J. Phys. Oceanogr. 2015, 45, 1804-1820. [CrossRef]

27. Hawinkel, P.; Thiery, W.; Lhermitte, S.; Swinnen, E.; Verbist, B.; Van Orshoven, J.; Muys, B. Vegetation response to precipitation variability in East Africa controlled by biogeographical factors. J. Geophys. Res. Biogeosci. 2016, 121, 2422-2444. [CrossRef]

28. Reason, C.J.C. Subtropical Indian Ocean SST dipole events and southern African rainfall. Geophys. Res. Lett. 2001, 28, 2225-2227. [CrossRef]

29. Saji, N.H.; Yamagata, T. Possible impact of Indian Ocean dipole mode events on global climate. Clim. Res. 2003, 25, 151-169. [CrossRef]

30. Behera, S.K.; Luo, J.J.; Masson, S.; Rao, S.A.; Sakum, H.; Yamagata, T. A CGCM study on the interaction between IOD and ENSO. J. Clim. 2006, 19, 1688-1705. [CrossRef]

31. Marchant, R.; Mumbi, C.; Behera, S.; Yamagata, T. The Indian Ocean dipole-the unsung driver of climatic variability in East Africa. Afr. J. Ecol. 2007, 45, 4-16. [CrossRef]

32. Williams, C.A.; Hannan, N.P. ENSO and IOD teleconnections for African ecosystems: Evidence of destructive interference between climate oscillations. Biogeosciences 2011, 8, 27-40. [CrossRef]

33. Manatsa, D.; Chipindu, B.; Behera, S.K. Shifts in IOD and their impacts on association with East Africa rainfall. Theor. Appl. Clim. 2012, 110, 115-128. [CrossRef]

34. Gaughan, A.E.; Staub, C.G.; Hoell, A.; Weaver, A.; Waylen, P.R. Inter-and intra-annual precipitation variability and associated relationships to ENSO and the IOD in southern Africa. Int. J. Clim. 2015, 36, 1643-1656. [CrossRef]

35. Todd, M.C.; Washington, R. Climate variability in central equatorial Africa: Influence from the Atlantic sector. Geophys. Res. Lett. 2004, 31, L23202. [CrossRef]

36. Jury, M.R.; Matari, E.; Matitu, M. Equatorial African climate teleconnections. Theor. Appl. Clim. 2009, 95, 407-416. [CrossRef]

37. Vignaud, N.; Richard, Y.; Roualt, M.; Fauchereau, N. Water vapor transport from the tropical Atlantic and summer rainfall in tropical southern Africa. Clim. Dyn. 2007, 28, 113-123. [CrossRef]

38. Laing, A.G.; Carbone, R.E.; Levizzani, V. Cycles and propagation of deep convection over equatorial Africa. Mon. Weather Rev. 2011, 139, 2832-2853. [CrossRef]

39. Shannon, L.V.; Boyd, A.J.; Brundrit, G.B.; Taunton-Clark, J. On the existence of an El Niño-type phenomenon in the Benguela system. J. Mar. Res. 1986, 44, 495-520. [CrossRef] 
40. Hastenrath, S.L. Climate Dynamics of the Tropics; Kluwer Academic Publishers: Dordrecht, The Netherlands, 1991; p. 512.

41. Jury, M.R. Climate and weather factors modulating river flows in southern Angola. Int. J. Clim. 2010, 30, 901-908. [CrossRef]

42. NOAA NCEP CPC FEWS Africa Daily ARC2 Daily. Available online: https://iridl.ldeo.columbia.edu/ SOURCES/.NOAA/.NCEP/.CPC/.FEWS/.Africa/.DAILY/.ARC2/.daily/ (accessed on 22 July 2019).

43. Novella, N.S.; Thiaw, W.M. African rainfall climatology version 2 for famine early warning systems. J. Appl. Meteorol. Clim. 2013, 52, 588-606. [CrossRef]

44. Hijmans, R.J.; van Etten, J. Raster: Geographic Analysis and Modeling with Raster Data. R Package Version 2.0-12. 2012. Available online: http://CRAN.R-project.org/package=raster (accessed on 22 July 2019).

45. Wolter, K.; Timlin, M.S. El Niño/Southern Oscillation behaviour since 1871 as diagnosed in an extended multivariate ENSO index (MEI. ext.). Int. J. Clim. 2011, 31, 1074-1087. [CrossRef]

46. Extended Multivariate ENSO Index (MEI. ext.). Available online: http://www.esrl.noaa.gov/psd/enso/mei. ext/index.html (accessed on 22 July 2019).

47. Nicholson, S.E.; Entekhabi, M.D. The quasi-periodic behavior of rainfall variability in Africa and its relationship to the Southern Oscillation. Arch. Meteorol. Geophys. Bioklimatol. Ser. A 1986, 34, 311-348. [CrossRef]

48. Nicholson, S.E. The nature of rainfall variability over Africa on time scales of decades to millennia. Glob. Planet. Chang. 2000, 26, 137-158. [CrossRef]

49. Katz, R.W.; Brown, B.G. The problem of multiplicity in research on teleconnections. Int. J. Clim. 1991, 11, 505-515. [CrossRef]

50. McKee, T.B.; Doesken, N.J.; Kleist, J. The relationship of drought frequency and duration to time scales. In Proceedings of the 8th Conference on Applied Climatology; American Meteorological Society: Boston, MA, USA, 1993; Volume 17, pp. 179-183.

51. Guttman, N.B. Accepting the standardized precipitation index: A calculation algorithm. J. Am. Water Resour. Assoc. 1999, 35, 311-322. [CrossRef]

52. Du, Y.; Cai, W.; Wu, Y. A new type of the Indian Ocean Dipole since the mid-1970s. J. Clim. 2013, 26, 959-972. [CrossRef]

53. Ummenhofer, C.C.; England, M.H.; McIntosh, P.C.; Meyers, G.A.; Pook, M.J.; Risbey, J.S.; Gupta, A.S.; Taschetto, A.S. What causes southeast Australia's worst droughts? Geophys. Res. Lett. 2009, 36, L04706. [CrossRef]

54. Mercier, F.; Cazenave, A.; Maheu, C. Interannual lake level fluctuations (1993-1999) in Africa from Topex/Poseidon: Connections with ocean-atmosphere interactions over the Indian Ocean. Glob. Planet. Chang. 2002, 32, 141-163. [CrossRef]

55. Birkett, C.; Murtugudde, R.; Allan, T. Indian Ocean climate event brings floods to East Africa's lakes and the Sudd Marsh. Geophys. Res. Lett. 1999, 26, 1031-1034. [CrossRef]

56. Goddard, L.; Graham, N.E. Importance of the Indian Ocean for simulating rainfall anomalies over eastern and southern Africa. J. Geophys. Res. Atmos. 1999, 104, 19099-19116. [CrossRef]

57. Anyamba, A.; Tucker, C.J.; Mahoney, R. From El Niño to La Niña: Vegetation response patterns over East and Southern Africa during the 1997-2000 period. J. Clim. 2002, 15, 3096-3103. [CrossRef]

(C) 2019 by the authors. Licensee MDPI, Basel, Switzerland. This article is an open access article distributed under the terms and conditions of the Creative Commons Attribution (CC BY) license (http://creativecommons.org/licenses/by/4.0/). 